Article

\title{
Sol-Gel-Derived Hydroxyapatite-Carbon Nanotube/Titania Coatings on Titanium Substrates
}

\author{
Xiaoli Ji ${ }^{1, \dagger}$, Weiwei Lou ${ }^{1, \dagger}$, Qi Wang ${ }^{2}$, Jianfeng Ma ${ }^{1}$, Haihong Xu ${ }^{1}$, Qing Bai ${ }^{1}$, \\ Chuantong Liu ${ }^{1}$ and Jinsong Liu ${ }^{1, *}$
}

1 Department of Prosthodontics, School and Hospital of Stomatology, Wenzhou Medical College, Wenzhou 325027, China; E-Mails: jixiaoli214@163.com (X.J.); louweiwei1125@163.com (W.L.); dentistmacn@yahoo.cn (J.M.); zhejiao1985@163.com (H.X.); qingqing_8429@126.com (Q.B.); dentliu@qq.com (C.L.)

2 State Key Laboratory of Oral Diseases, West China Stomatology Hospital, Sichuan University, Chengdu 610041, China; E-Mail: wqinno_875@163.com

$\dagger$ These authors contributed equally to this work.

* Author to whom correspondence should be addressed; E-Mail: caraln@yahoo.cn; Tel./Fax: +86-577-88063030.

Received: 29 February 2012; in revised form: 9 March 2012 / Accepted: 18 April 2012 / Published: 24 April 2012

\begin{abstract}
In this paper, hydroxyapatite-carbon nanotube/titania (HA-CNT/ $\left.\mathrm{TiO}_{2}\right)$ double layer coatings were successfully developed on titanium (Ti) substrates intended for biomedical applications. A $\mathrm{TiO}_{2}$ coating was firstly developed by anodization to improve bonding between HA and Ti, and then the layer of HA and CNTs was coated on the surface by the sol-gel process to improve the biocompatibility and mechanical properties of Ti. The surfaces of double layer coatings were uniform and crack-free with a thickness of about $7 \mu \mathrm{m}$. The bonding strength of the $\mathrm{HA}-\mathrm{CNT} / \mathrm{TiO}_{2}$ coating was higher than that of the pure HA and HA-CNT coatings. Additionally, in vitro cell experiments showed that CNTs promoted the adhesion of preosteoblasts on the $\mathrm{HA}-\mathrm{CNT} / \mathrm{TiO}_{2}$ double layer coatings. These unique surfaces combined with the osteoconductive properties of HA exhibited the excellent mechanical properties of CNTs. Therefore, the developed $\mathrm{HA}-\mathrm{CNT} / \mathrm{TiO}{ }_{2}$ coatings on Ti substrates might be a promising material for bone replacement.
\end{abstract}

Keywords: hydroxyapatite; carbon nanotubes; titania; anodization; sol-gel process 


\section{Introduction}

Titanium (Ti) has been widely used to fabricate biomedical materials because it has excellent biocompatibility, corrosion resistance, and mechanical properties [1,2]. However, the bio-inertness of the metallic surfaces inhibits the growth of bone tissue [3]. On the other hand, hydroxyapatite ( $\mathrm{HA} ; \mathrm{Ca}_{10}\left(\mathrm{PO}_{4}\right)_{6}(\mathrm{OH})_{2}$ ) was widely used in hard tissue engineering such as bone and dentin formation, owing to its excellent osteoconductivity and biocompatibility [4]. However, the brittle nature and low fracture toughness of HA prevented its clinical application under load-bearing conditions. In order to overcome this shortage, HA has been applied as a coating on metallic surface, which combined the high mechanical strength of the metal with the excellent biocompatibility and bioactivity of the ceramic and is therefore suitable for implants in high load-bearing applications.

Carbon nanotubes (CNTs) exhibited outstanding mechanical, structural, thermal, chemical and optical properties [5-7], which attracted attention as reinforcement for high strength composites. CNTs have been added to HA to obtain nanocomposite coatings that combine the mechanical and biological properties of the individual materials and thus showed the improved mechanical performance [8,9]. Moreover, CNTs dissipated the residual stress in HA coatings [10].

Numerous strategies have been proposed to prepare HA, with the sol-gel method being the most favored. To prepare HA coatings from sol-gels, the calcium and phosphorus precursors were mixed at a molecular level for ensuring chemical homogeneity. In addition, the method is technically simple, cost-effective, and requires lower temperatures than do traditional processing methods $[11,12]$. Ti and HA have different thermal expansion coefficients, which may hinder the bonding strength between them. To improve the bonding between $\mathrm{HA}$ and $\mathrm{Ti}$, a titania $\left(\mathrm{TiO}_{2}\right)$ coating is formed on the Ti surface. Various methods have been adopted to form a $\mathrm{TiO}_{2}$ layer on the $\mathrm{Ti}$ substrate, such as anodization, thermal oxidation and the sol-gel process. Recently, anodization has been applied to obtain a rough, porous $\mathrm{TiO}_{2}$ layer on the surface of $\mathrm{Ti}[13,14]$. This method is attractive because the $\mathrm{TiO}_{2}$ layer can be controlled by adjusting the processing conditions.

In this study, we intended to develop a novel method for fabricating $\mathrm{HA}-\mathrm{CNT} / \mathrm{TiO}_{2}$ double layer coatings on Ti substrates. Firstly, we developed a $\mathrm{TiO}_{2}$ by anodization. Then, the HA-CNT composite coating was coated on top of the $\mathrm{TiO}_{2}$ layer by the sol-gel process. The crystallization of the HA phase and the microstructure of the double layer coatings were investigated. The bonding strength of the coatings and their in vitro biological properties were also evaluated.

\section{Results and Discussion}

\section{1. $\mathrm{TiO}_{2}$ Coating Phase and Morphology}

Heat treatment plays a vital role in the synthesis of $\mathrm{TiO}_{2}$ coatings, since it affects their morphology, crystallinity, and porosity and induces phase transformations. The crystalline forms of the $\mathrm{TiO}_{2}$ layer on the Ti substrate were analyzed before and after heat treatment at two temperatures (Figure 1). Before heat treatment, the XRD spectra of the $\mathrm{TiO}_{2}$ layer showed only reflections corresponding to the $\mathrm{Ti}$ substrate. Neither rutile nor anatase $\mathrm{Ti}$ crystalline phases were observed, indicating that the anodized film was amorphous $\mathrm{TiO}_{2}$. In order to remove water from the product, the layer should be calcined to a high temperature (above $450{ }^{\circ} \mathrm{C}$ ). Heat treatment at $450{ }^{\circ} \mathrm{C}$ afforded an anatase phase, 
while treatment at $700{ }^{\circ} \mathrm{C}$ yielded a rutile phase. $\mathrm{Hu}$ et al. [15] have reported that $\mathrm{TiO}_{2}$ normally undergone an anatase-to-rutile phase transition at around $600-700{ }^{\circ} \mathrm{C}$.

Figure 1. X-ray diffraction (XRD) spectra of the $\mathrm{TiO}_{2}$ layers before heat treatment (a) and after heat treatment at various temperatures for $1 \mathrm{~h}$ in air: (b) $450{ }^{\circ} \mathrm{C}$; (c) $700{ }^{\circ} \mathrm{C}$.

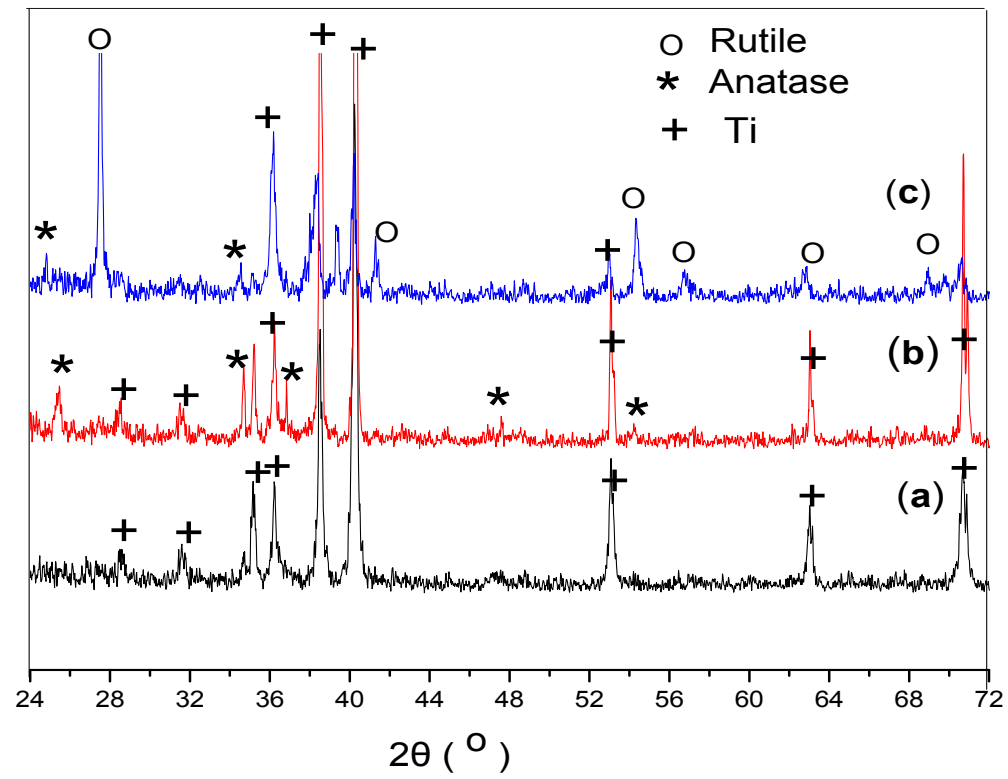

FEG-SEM observations revealed that the $\mathrm{TiO}_{2}$ structure probably formed pores or nanotubes, depending on the anodization voltage (Figure 2). At $5 \mathrm{~V} \mathrm{TiO}_{2}$ formed only a rough surface (Figure 2a). With increasing voltage, the $\mathrm{TiO}_{2}$ layer showed a more three-dimensional structure that included numerous open pores (Figure 2b,c) [16]. It was found that the pores were uniform and arrange regularly, and their diameters varied from 50 to $200 \mathrm{~nm}$ when the voltage was changed. At the highest applied voltage, the surface became cracked and irregular (Figure 2d), which was in agreement with the results reported by Ishizawa et al. [17]. Compared with the untreated Ti substrate, the anodized substrates showed rougher surface morphologies and a greater number of pores.

Figure 2. Field-emission gun scanning electron microscopy (FEG-SEM) images of the $\mathrm{TiO}_{2}$ surface structures obtained by anodizing the Ti substrates, at different voltages before heat treatment: (a) $5 \mathrm{~V}$; (b) $10 \mathrm{~V}$; (c) $20 \mathrm{~V}$; (d) $30 \mathrm{~V}$.
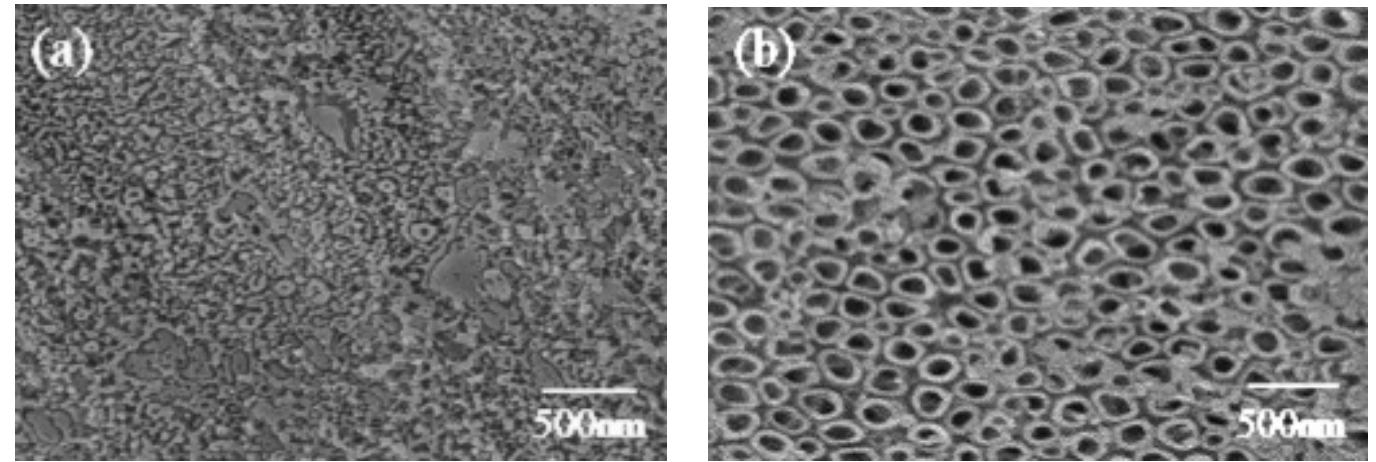
Figure 2. Cont.
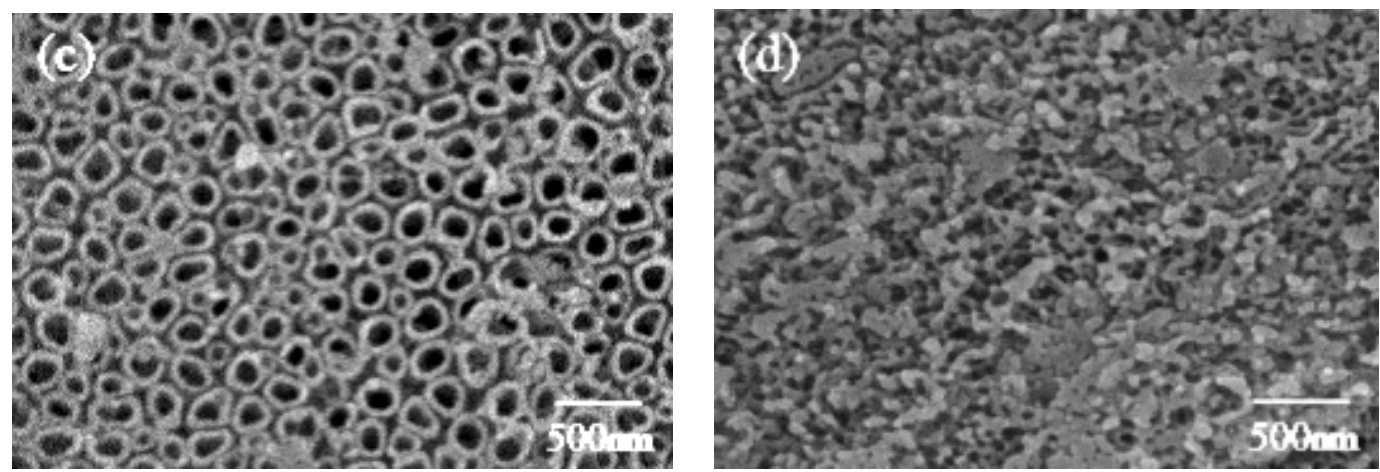

\subsection{Double Layer Coating Phase and Morphology}

Figure 3 shows the XRD patterns of the $\mathrm{HA}-\mathrm{CNT} / \mathrm{TiO}_{2}$ (Figure $3 \mathrm{a}$ ) and $\mathrm{HA} / \mathrm{TiO}_{2}$ (Figure $3 \mathrm{~b}$ ) double layer coatings on $\mathrm{Ti}$ substrates. No extraneous peaks appeared under the heat treatment, only peaks for $\mathrm{HA}, \mathrm{CNTs}, \mathrm{TiO}_{2}$ and $\mathrm{Ti}$ were detected. Weak and broadened peaks in the spectra might be due to the small grains of the coatings. There was a branched double peak at $2 \theta=26^{\circ}$. Because the peak $\left(26^{\circ}\right)$ of CNTs overlapped with the peak $\left(25.8^{\circ}\right)$ of HA, the peak was weak and hardly confirmed CNTs in the double layer coatings. However, the existence of CNTs can be confirmed by SEM. The CNTs, as indicated by arrows in Figure 4e, were distributed in the HA matrix. These results suggested that the homogeneous dispersion of CNTs resulted in a higher rate of hydroxyapatite crystallization. The result was in agreement with the report by Najafi et al. [18], which showed that the synthesis of HA in the presence of CNTs had the best result in terms of homogenization of the carbon nanotube dispersion and faster crystallization of hydroxyapatite.

Figure 3. XRD spectra of the double layer coatings on Ti substrates after heat treatment at $550{ }^{\circ} \mathrm{C}$ for $30 \mathrm{~min}$ in air: (a) $\mathrm{HA}-\mathrm{CNT} / \mathrm{TiO}_{2}$ double layer coating; (b) $\mathrm{HA} / \mathrm{TiO}_{2}$ double layer coating. (O): $\mathrm{TiO}_{2} ;(+)$ : $\mathrm{HA} ;(*)$ : CNT.

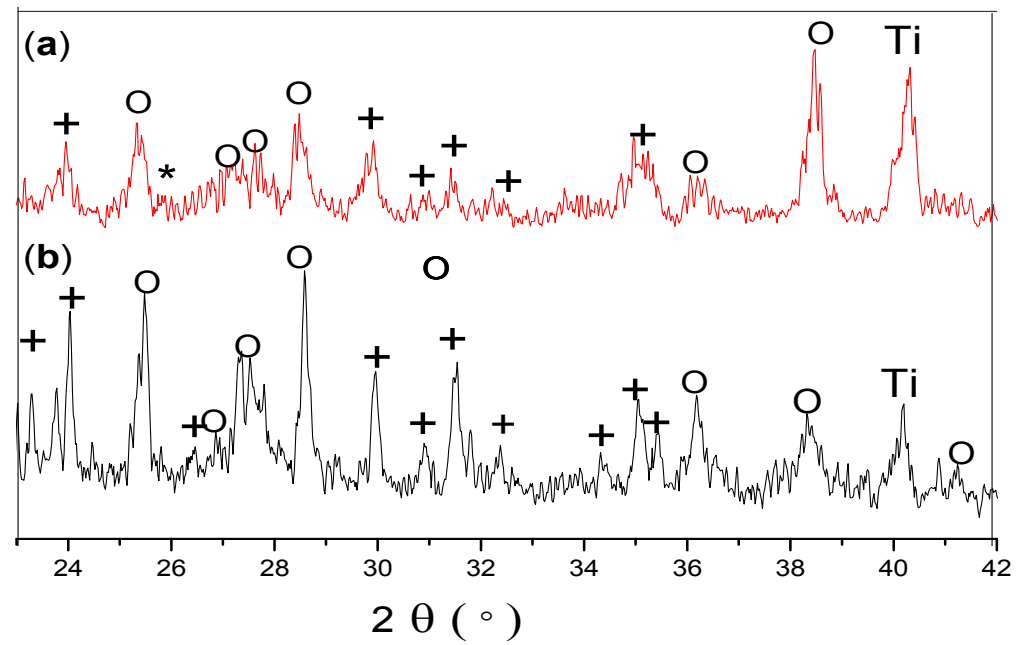


Figure 4. SEM images of the two coating systems on Ti substrate: (a) HA coating; (b) HA coating at high magnification; (c) $\mathrm{HA}-\mathrm{CNT} / \mathrm{TiO}_{2}$ double layer coating; (d) $\mathrm{HA}-\mathrm{CNT} / \mathrm{TiO}_{2}$ at high magnification; (e) micrograph of the fracture surface of the $\mathrm{HA}-\mathrm{CNT} / \mathrm{TiO}_{2}$ double layer coating; (f) $\mathrm{HA}-\mathrm{CNT} / \mathrm{TiO}_{2}$ double layer coating cross-sectional view.
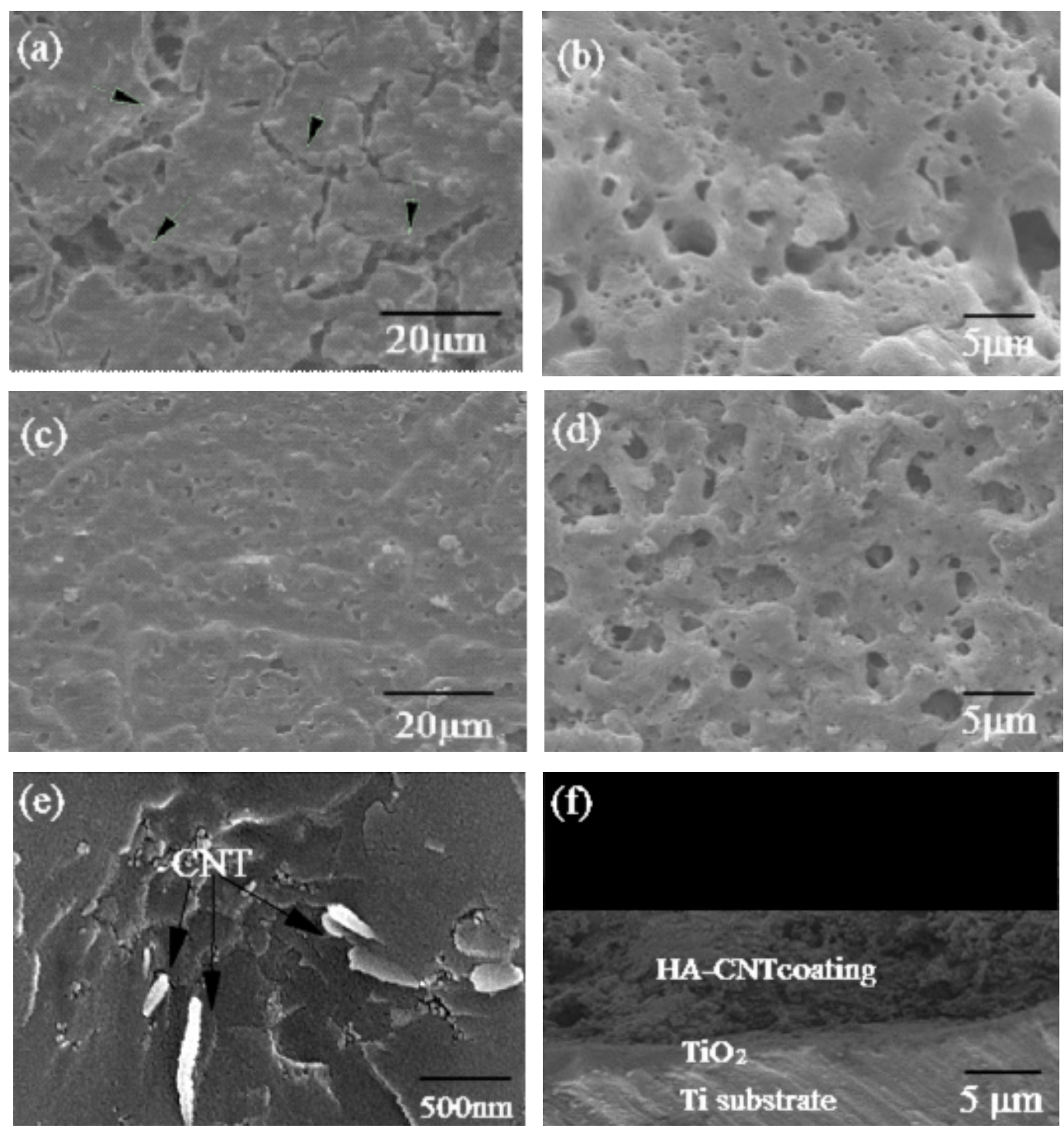

FTIR spectroscopy confirmed some features of the coatings that could not be observed by XRD analysis. The expected orthophosphate $\left(\mathrm{PO}_{4}{ }^{3-}\right)$ and hydroxyl $(-\mathrm{OH})$ peaks were clearly presented in the spectra of both HA coatings (Figure 5). The $\mathrm{PO}_{4}{ }^{3-}$ ions in the apatite structure gave a sharp and broad IR absorbance between 800 and $1100 \mathrm{~cm}^{-1}$. $\mathrm{PO}_{4}{ }^{3-}$ stretching and bending modes were seen at $557 \mathrm{~cm}^{-1}$, $944 \mathrm{~cm}^{-1}$, and $1121 \mathrm{~cm}^{-1}$. A broad peak at around $3000-3600 \mathrm{~cm}^{-1}$, centered at $3428 \mathrm{~cm}^{-1}$, could be attributed to $\mathrm{OH}$ stretching. Suchanek et al. have reported an $\mathrm{OH}$ vibration peak at around $630 \mathrm{~cm}^{-1}$ for $\mathrm{HA}$, but this peak was not evident in our spectra [19]. Interestingly, a $\mathrm{C}=\mathrm{O}$ stretching peak attributed to the carbonyl on the CNTs was visible at $1630 \mathrm{~cm}^{-1}$ (Figure $5 \mathrm{~A}$ ). 
Figure 5. Fourier transform infrared spectroscopy (FTIR) spectra of the double layer coatings on Ti substrates after heat treatment at $550{ }^{\circ} \mathrm{C}$ for $30 \mathrm{~min}$ in air: (A) HA-CNT/TiO${ }_{2}$ double layer coating; (B) $\mathrm{HA} / \mathrm{TiO}_{2}$ double layer coating.

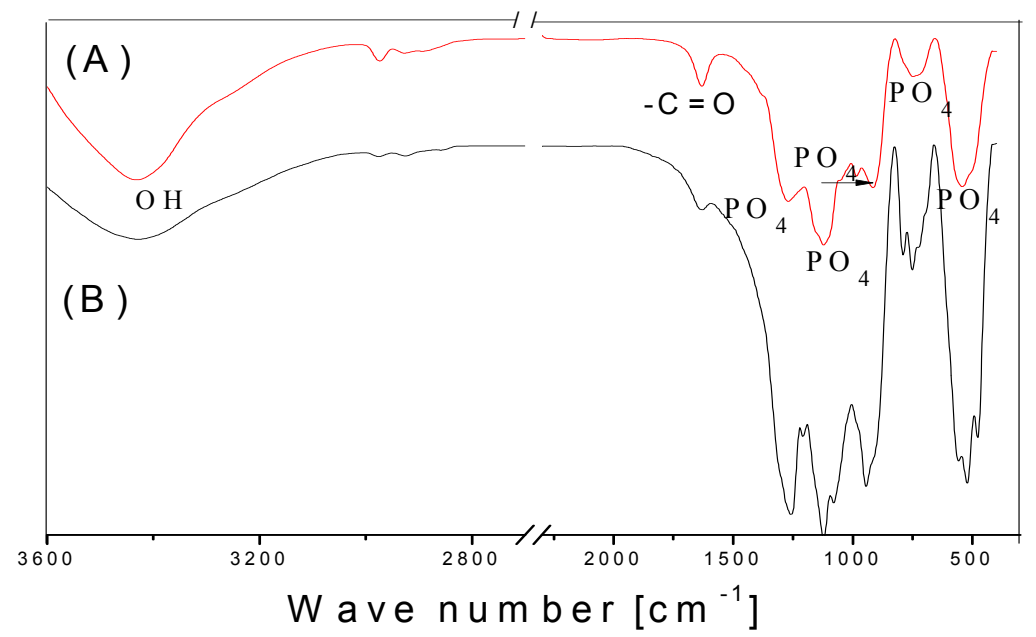

With the SEM observation, the morphologies of the HA and $\mathrm{HA}-\mathrm{CNT} / \mathrm{TiO}_{2}$ double layer coatings on the Ti substrate were slightly different. The $\mathrm{HA}-\mathrm{CNT} / \mathrm{TiO}_{2}$ double layer coatings appeared to be highly dense and uniform, while the simple HA coating had numerous microcracks (Figure 4a,c). The discrepancy in the thermal expansion coefficients between HA $\left(15.2 \times 10^{-6}{ }^{\circ} \mathrm{C}^{-1}\right)$ and $\mathrm{Ti}\left(8.6 \times 10^{-6}{ }^{\circ} \mathrm{C}^{-1}\right)$ probably resulted in excessive strain during the heating and cooling processes. In our method, the mismatch of thermal expansion coefficients between them was reduced by $\mathrm{TiO}_{2}$ layer $\left(9.0 \times 10^{-6}{ }^{\circ} \mathrm{C}^{-1}\right)$. The anodized coatings helped in reducing the microcracks, also yielding a denser coating [20]. Moreover, CNTs further reduced the crack propagation because of their function in transferring and eliminating residual stress in the HA/CNTs composite coatings, which had been proved by Lin et al [21]. The $\mathrm{HA}$ and $\mathrm{HA}-\mathrm{CNT} / \mathrm{TiO}_{2}$ double layer coatings had similar rough surface microstructures at high magnification (Figure $4 \mathrm{~b}, \mathrm{~d}$ ). The rough surface of the HA coatings has been reported to be advantageous for cell attachment and proliferation [22].

The cross sectional surface of coatings showed that the coatings with a uniform thickness of about $7 \mu \mathrm{m}$ were very compact and dense (Figure $4 \mathrm{f}$ ). No pores or microcracks were detected in the coatings. The layer bonded firmly to the substrate and held a uniform thickness throughout the Ti surface. Moreover, there were no delaminations or cracks at the interlayer/topcoat interface, suggesting that both $\mathrm{Ti}$ substrate/TiO $\mathrm{Tin}_{2}$ interlayer and $\mathrm{TiO}_{2}$ interlayer/HA-CNT topcoat interfaces had very good bonding capabilities.

\subsection{Bonding Properties}

To evaluate the mechanical properties of the double layer coatings, the bonding strength of the different coatings was measured, and the results presented in Figure 6. As expected, the insertion of the $\mathrm{TiO}_{2}$ layer and CNTs significantly improved the bonding strength of the layer to the Ti substrate. The $\mathrm{HA}-\mathrm{CNT} / \mathrm{TiO}_{2}$ double layer coatings bound more strongly than the $\mathrm{HA}, \mathrm{HA} / \mathrm{TiO}_{2}$ and $\mathrm{HA}-\mathrm{CNT}$ coatings $(p<0.05)$. The bonding strength of the $\mathrm{HA}-\mathrm{CNT} / \mathrm{TiO}_{2}$ double layer coatings increased to as high as $35.2 \mathrm{MPa}$, which constituted an approximately $65.9 \%$ enhancement with respect to that of the 
HA single coating (21.2 $\mathrm{MPa})$ and was much higher than that of electrophoretic deposition HA coatings [9]. The HA-CNT layer bonded more tightly to the $\mathrm{TiO}_{2}$ layer than to the bare $\mathrm{Ti}$ substrate. Because the mismatch of the thermal expansion coefficients of HA and Ti was alleviated by the addition of $\mathrm{TiO}_{2}$, resulting in the decreased residual stress in the coatings. These results proved that the oxidation of Ti substrate improved the attachment of HA to metal substrates, which was in agreement with the findings of Hautaniemi et al. [23]. The CNTs also helped prevent the HA-CNT coating from peeling off by acting as a reinforcement network [24].

Figure 6. Bonding strengths of different coatings deposited on Ti substrates.

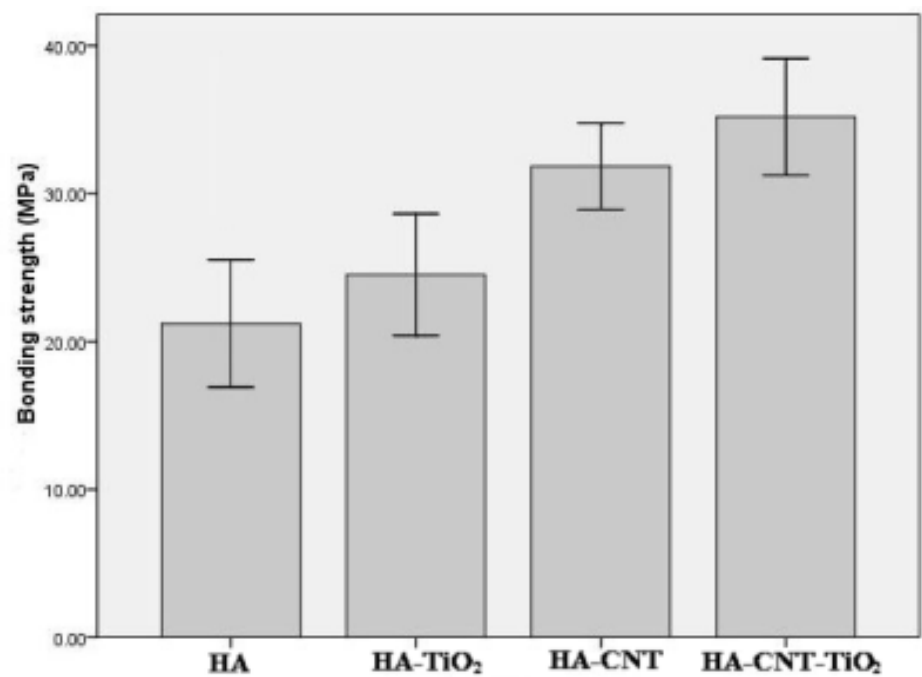

The images of the failure surfaces of $\mathrm{HA}-\mathrm{CNT} / \mathrm{TiO}_{2}$ and $\mathrm{HA}-\mathrm{CNT}$ double layer coatings after adhesion strength tests were shown in Figure 7. Failure occurred entirely at the Ti substrate/coating interface for the HA-CNT coating (Figure 7a), While some debris of the coatings remained on the surface of $\mathrm{HA}-\mathrm{CNT} / \mathrm{TiO}_{2}$ double layer coatings, which showed failure occurred between interlayer and topcoat (Figure 7b). Based on these results, it was confirmed that the bonding strength of the coating layer was dictated by the coating defects and the substrate type.

Figure 7. Morphology of failed surface of (a) HA-CNT and (b) $\mathrm{HA}-\mathrm{CNT} / \mathrm{TiO}_{2}$ showing the coatings peeled off from the substrate after adhesion test.
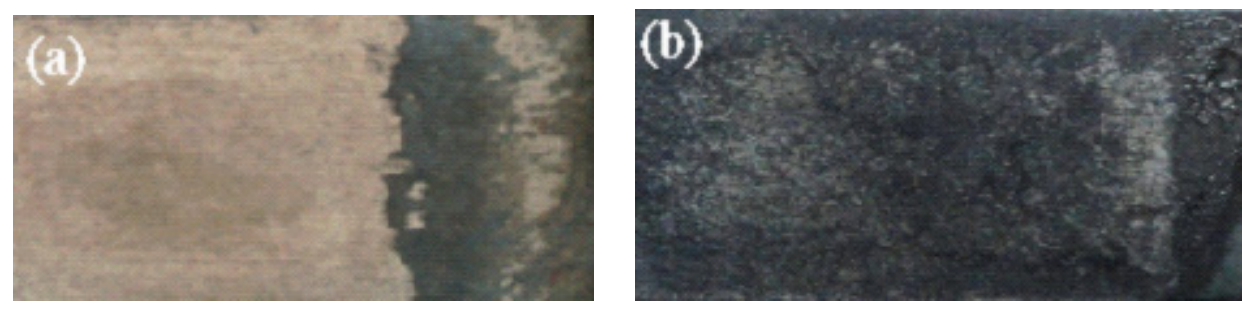

\subsection{In Vitro Cellular Assessment}

In order to evaluate cell attachment to the coatings, preosteoblast MC3T3-E1 cells were fixed after $24 \mathrm{~h}$ of culturing with the different coatings and imaged (Figure 8). As is shown in Figure 8a, the cells 
did not spread out well on the bare Ti control. By contrast, the cells on the HA coating gradually adhered to and spread out on the substrates (Figure $8 \mathrm{~b}$ ). Furthermore, the cells on the HA-CNT/TiO 2 double layer spread out further and had more filopods than those on the bare $\mathrm{Ti}$ and the $\mathrm{HA} / \mathrm{TiO}_{2}$ coating (Figure 8c). The anodized substrates, which have rougher surface morphologies and numerous micron-sized pores, could improve protein adhesion. Moreover, the porous edges were beneficial for cell adhesion [25]. Recent studies have demonstrated that osteoblast cells adhered to the surface of functionalized MWCNTs. Zanello et al. tried to control cell growth on CNTs by functionalizing them and demonstrated that neutrally charged CNTs sustained osteoblast growth and bone formation [26]. These results indicate that during the initial incubation, the anodized Ti and CNTs in the double layer coating promoted preosteoblast cell attachment and adhesion.

Figure 8. SEM images of preosteoblast MC3T3-E1 cells growing on each sample after 24 h of incubation: (a) bare Ti; (b) HA coating; and (c) $\mathrm{HA}-\mathrm{CNT} / \mathrm{TiO}_{2}$ double layer coating. $\mathrm{TiO}_{2}$ was heat-treated at $450{ }^{\circ} \mathrm{C}$ for $1 \mathrm{~h}$.
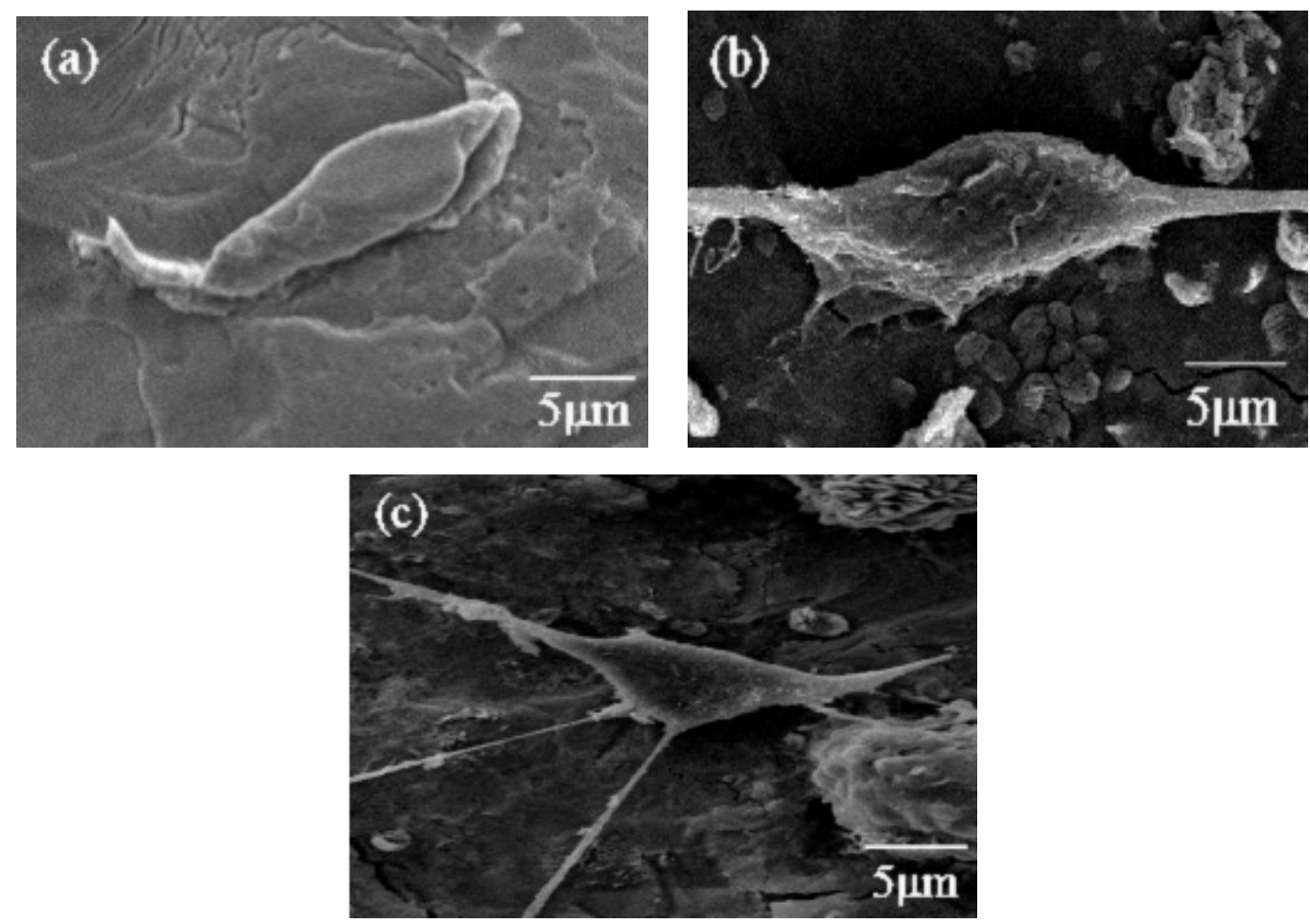

To assay proliferation on the different coatings, preosteoblast MC3T3-E1 cells were cultured on each material for $5 \mathrm{~d}$. Cell proliferation was enhanced on each HA coating when compared to that on bare $\mathrm{Ti}$ (Figure 9). All the coatings ( $\mathrm{HA}, \mathrm{HA} / \mathrm{TiO}_{2}, \mathrm{HA}-\mathrm{CNT}$, and $\mathrm{HA}-\mathrm{CNT} / \mathrm{TiO}_{2}$ ) were assayed, and the $\mathrm{HA}-\mathrm{CNT} / \mathrm{TiO}_{2}$ double layer coating showed a significantly higher cell proliferation rate relative to the pure HA coating $(P<0.01)$. A study by George et al. tested the response of MWCNTs to human lung epithelial cells, osteoblast-like cells and primary osteoblast cells. They suggested that the dimensions and spacing of CNTs may be key to determining subsequent cell spreading and proliferation [27]. The findings in this research also suggest that adding CNTs to HA coatings enhance its bioactive properties. 
Figure 9. Proliferation of MC3T3-E1 cells cultured on each sample for $5 \mathrm{~d}$. Bare Ti substrate was used as a control.

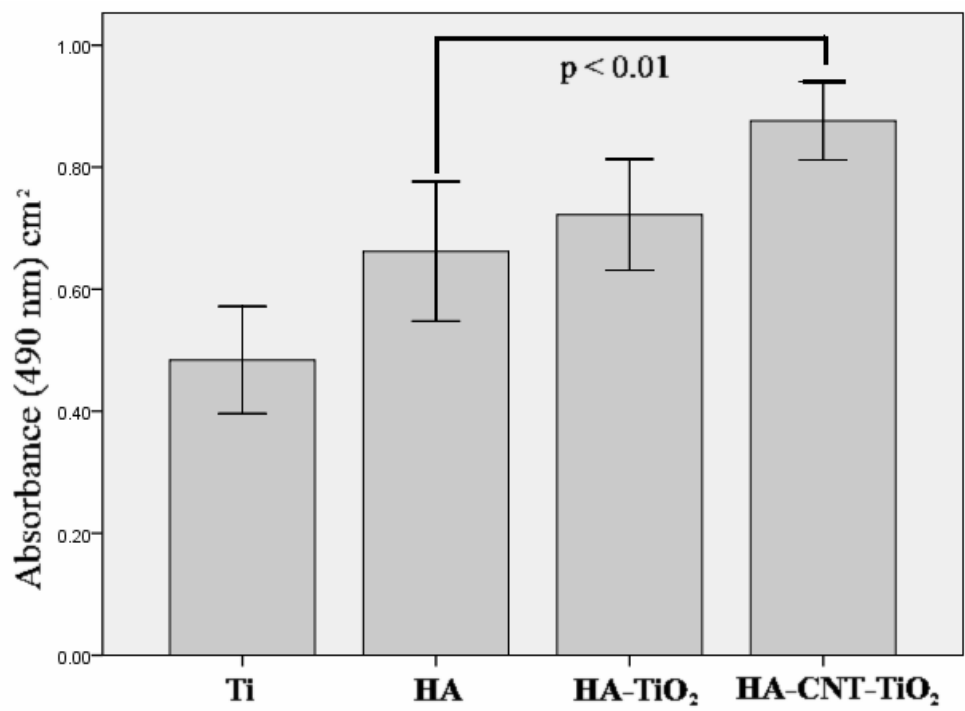

\section{Experimental Section}

\subsection{Preparation of Ti Substrates}

Ti sheets $\left(\mathrm{TA}_{2}\right.$, Baoji Non-ferrous Metals Co., China) measuring $10 \times 10 \times 2 \mathrm{~mm}$ were used as the substrates. Their surfaces were polished with silicon carbide papers (grit \#180, 320, 600, 800, and 1000), followed by ultrasonic cleaning in acetone, ethanol, and distilled water. Before the experiment, samples were etched in an acidic solution $\left(\mathrm{HF} / \mathrm{HNO}_{3} / \mathrm{H}_{2} \mathrm{O}=1: 3: 10\right)$ for $3 \mathrm{~min}$ to remove the oxide layer that naturally formed in air atmosphere.

\subsection{Preparation of $\mathrm{HA}-\mathrm{CNT} / \mathrm{TiO}_{2}$ Coating}

Samples were anodized at room temperature with a direct current power supply. A graphite plate and the Ti sample were used as the cathode and the anode, respectively. The substrates were anodized in $\mathrm{HF} / \mathrm{H}_{2} \mathrm{O}$ with $\mathrm{H}_{3} \mathrm{PO}_{4}$ at 5-30 V for $1 \mathrm{~h}$ to form nanostructured Ti surfaces. The solution was stirred to homogenize the electrolyte and allow gasses to escape from the Ti surface. After anodization, the samples were cleaned with distilled water, dried, and then heat treated at $450{ }^{\circ} \mathrm{C}$ or $700{ }^{\circ} \mathrm{C}$ in air for $2 \mathrm{~h}$. After heat treatment, the samples were ultrasonically cleaned in acetone, ethanol, and distilled water and finally dried to obtain the $\mathrm{TiO}_{2}$ film.

The HA sol was fabricated from its precursors, $\mathrm{Ca}\left(\mathrm{NO}_{3}\right)_{2} \cdot 4 \mathrm{H}_{2} \mathrm{O}$ and $\mathrm{P}_{2} \mathrm{O}_{5}$. Stoichiometric amounts of $\mathrm{Ca}\left(\mathrm{NO}_{3}\right)_{2} \cdot 4 \mathrm{H}_{2} \mathrm{O}$ and $\mathrm{P}_{2} \mathrm{O}_{5}$ were dissolved in separate ethanol solutions. Next, the $\mathrm{P}_{2} \mathrm{O}_{5}$ solution was slowly added to the $\mathrm{Ca}\left(\mathrm{NO}_{3}\right)_{2} \cdot 4 \mathrm{H}_{2} \mathrm{O}$ solution to achieve a calcium $(\mathrm{Ca}) /$ phosphorus $(\mathrm{P})$ ratio $=1.67$. Then, $1 \mathrm{wt} \%$ carboxyl-multiwalled CNTs (MWCNTs) with a diameter of 10-20 nm and length of 0.5-2 $\mu \mathrm{m}$ (Chengdu Institute of Organic Chemistry, China) were added to the HA sol with vigorous stirring for $24 \mathrm{~h}$; the resulting mixture was subsequently aged at room temperature for $48 \mathrm{~h}$ to obtain a clear sol. Carboxylated MWCNTs are easily dispersible in solvents. 
Next, the anodized Ti substrates (anodized in $\mathrm{HF} / \mathrm{H}_{2} \mathrm{O}$ with $\mathrm{H}_{3} \mathrm{PO}_{4}$ at $20 \mathrm{~V}$ for $1 \mathrm{~h}$ and heat treated at $450{ }^{\circ} \mathrm{C}$ ) were slowly dipped into the composite sols at a withdrawing rate of $5 \mathrm{~cm} / \mathrm{min}$. As a comparison, the Ti substrates and the anodized Ti substrates were dipped into the HA sols. The gels obtained from the sols were dried at $150{ }^{\circ} \mathrm{C}$ for $30 \mathrm{~min}$ and then heat-treated at $550{ }^{\circ} \mathrm{C}$ for $30 \mathrm{~min}$ in order to fix the double layer coatings. Controls with pure HA and HA-CNT (no $\mathrm{TiO}_{2}$ ) were also tested and characterized.

\subsection{Characterization}

The crystalline phases in the coatings were analyzed by X-ray diffraction (XRD; D8 Focus, Bruker Co., Germany) and Fourier transform infrared spectroscopy (FTIR; Equinox 55, Bruker Co., Germany). For FTIR analysis, the coating was scraped off from the treated surface, mixed with high-purity $\mathrm{KBr}$ powder, and compacted into pellet form. The surface and cross-sectional morphologies of the double layer coatings were studied by Field-emission gun scanning electron microscopy (FEG-SEM) (JSM-6700F, JEOL Co., Japan) and scanning electron microscopy (SEM; S3000N, Hitachi Co., Japan).

The bonding strength of each coating layer was measured by adhering the double layer coating to an uncoated Ti plate with epoxy resin cured at $100{ }^{\circ} \mathrm{C}$ for $1.5 \mathrm{~h}$. After cooling, the Ti plate was pulled away at a loading rate of $1 \mathrm{~mm} / \mathrm{min}$ until the coating layer failed, and the bonding strength was determined by dividing the maximum load by the surface area. Five identical specimens were tested for each data point, which is represented as mean \pm SD $(n=5)$. Single factor analysis of variance (ANOVA) technique was used to assess the statistical significance of results between groups.

\subsection{In Vitro Cellular Assessment}

Specimens were sterilized in $120{ }^{\circ} \mathrm{C}$ steam for $1 \mathrm{~h}$ and then placed in 24-well plates. MC3T3-E1 preosteoblast cells, at a density of $1 \times 10^{4}$ cells $/ \mathrm{mL}$, were plated on each specimen, and $\mathrm{CP} \mathrm{Ti}$ (unalloyed commercially pure $\mathrm{Ti}$ ) was used as a control. The cells were cultured in $\alpha$-minimum essential medium ( $\alpha$-MEM; GIBCO, USA) supplemented with $10 \%$ fetal bovine serum (FBS; GIBCO, USA), $2 \mathrm{mM}$ L-glutamine, and $100 \mathrm{U} / \mathrm{mL}$ penicillin at $37{ }^{\circ} \mathrm{C}$ in humidified $5 \% \mathrm{CO}_{2}$. After $24 \mathrm{~h}$ of incubation, the cells were washed with phosphate-buffered saline (PBS) solution; then, the cells were detached using a trypsin-EDTA solution, and the living cells were counted using a haemocytometer (Superior Co., Germany). To observe the cell morphology, the specimens were fixed in 2.5\% glutaraldehyde for $4 \mathrm{~h}$ at $4^{\circ} \mathrm{C}$ and dehydrated gradually in $70 \%, 80 \%, 90 \%$, and $95 \%(\mathrm{v} / \mathrm{v})$ ethanol solutions for $15 \mathrm{~min}$ each and then twice in absolute ethanol. For examination by SEM (S3000N, Hitachi Co., Japan), surfaces with immobilized cells were dehydrated by critical point drying and coated with gold.

Cell activity was determined by using 3-(4,5-dimethylthiazol-2-yl)-2,5-diphenyl tetrazolium bromide (MTT) assay, The cells $\left(3 \times 10^{4}\right.$ cells $\left./ \mathrm{mL}\right)$ were seeded on the coating specimens in 24-well plates containing $\alpha$-MEM and placed for 5 days at $37{ }^{\circ} \mathrm{C}$, then washed with PBS solution, $20 \mu \mathrm{L}$ of MTT $(5 \mathrm{mg} / \mathrm{mL})$ was added to each well and incubated for $4 \mathrm{~h}$ at $37{ }^{\circ} \mathrm{C}$. At the end of the assay, the blue formazan reaction product was dissolved by adding $100 \mu \mathrm{L}$ dimethyl sulphoxide (DMSO) and transferred to a 96-well plate. The absorbance was determined at a wavelength of $490 \mathrm{~nm}$ using a microplate reader (Infinite ${ }^{\circledR}$ M200 PRO, Tecan Group Ltd., Switzerland). 


\section{Conclusions}

Uniform, crack-free $\mathrm{HA}-\mathrm{CNT} / \mathrm{TiO}_{2}$ double layer coatings were successfully fabricated on $\mathrm{Ti}$ substrates, which a $\mathrm{TiO}_{2}$ interlayer obtained by means of anodization and a HA-CNT composite topcoat deposited by sol-gel process. The $\mathrm{HA}-\mathrm{CNT} / \mathrm{TiO}_{2}$ double layer coatings had the highest bonding strength, showing resistance up to $35.2 \mathrm{MPa}$, which were much higher than that of electrophoretic deposition HA coatings. The insertion of the $\mathrm{TiO}_{2}$ layer and CNTs in the coatings promoted preosteoblast cell adhesion and proliferation. These findings suggest that adding CNTs to HA coatings affords promising materials for bone replacement. Furthermore, this study suggests that a $\mathrm{TiO}_{2}$ bonding coat, introduced via anodization, may be useful to improve the adhesion of $\mathrm{HA}$ and $\mathrm{HA}-\mathrm{TiO}_{2}$ coatings to titanium substrates.

\section{Acknowledgements}

This work was supported by Nature Science Foundation of Zhejiang Province (grant number Y12H140011) and Undergraduate Scientific and Technological Innovation Project of Zhejiang Province (grant number 2011R413003).

\section{References}

1. Brash, J.L. Biomaterials in Canada: The first four decades. Biomaterials 2005, 26, 7209-7220.

2. Liu, D.P.; Majewski, P.; O’Neill, B.K.; Ngothai, Y.; Colby, C.B. The optimal SAM surface functional group for producing a biomimetic HA coating on Ti. J. Biomed. Mater. Res. A 2006, $77 A, 763-772$.

3. Liu, X.; Chu, P.K.; Ding, C. Surface modification of titanium, titanium alloys, and related materials for biomedical applications. J. Mater. Sci. Eng. 2004, 47, 49-121.

4. Ruksudjarit, A.; Pengpat, K.; Rujijanagul, G.; Tunkasiri, T. Synthesis and characterizationof nanocrystalline hydroxyapatite from natural bovine bone. Curr. Appl. Phys. 2008, 8, 270-272.

5. Iijima, S. Helical microtubules of graphitic carbon. Nature 1991, 354, 56-58.

6. Esawi, A.M.; Farag, M.M. Carbon nanotube reinforced composites: Potential and current challenges. Mater. Des. 2007, 28, 2394-2401.

7. Lu, L.; Zhai, Y.H.; Zhang, Y.; Ong, C.; Guo, S. Reinforcement of hydrogenated carboxylated nitrile-butadiene rubber by multi-walled carbon nanotubes. Appl. Surf. Sci. 2008, 255, 2162-2166.

8. Boccaccini, A.R.; Cho, J.; Subhani, T.; Kaya, C.; Kaya, F. Electrophoretic deposition of carbon nanotube-ceramic nanocomposites. J. Eur. Ceram. Soc. 2010, 30, 1115-1129.

9. Kaya, C.; Singh, I.; Boccaccini, A.R. Multi-walled carbon nanotube reinforced hydroxyapatite layers of Ti6A14V medical implants by electrophoretic deposition (EPD). Adv. Eng. Mater. 2008, 10, 131-138.

10. Lin, C.; Han, H.; Zhang, F.; Li, A. Electrophoretic deposition of HA/MWNTs composite coating for biomaterial applications. J. Mater. Sci. Mater. Med. 2008, 19, 2569-7254.

11. Bezzi, G.; Celotti, G.; Landi, E.; La Toretta, T.M.G.; Sopyan, I.; Tamperi, A. A novel sol-gel technique for hydroxyapatite preparation. Mater. Chem. Phys. 2003, 78, 816-824. 
12. Kim, H.W.; Koh, Y.H.; Li, L.H.; Lee, S.; Kim, H.E. Hydroxyapatite coating on titanium substrate with titania buffer layer processed by sol-gel method. Biomaterials 2004, 25, 2533-2538.

13. Cui, X.; Kim, H.M.; Kawashit, M.; Wang, L.; Xiong, T.; Kokubo, T.; Nakamura, T. Preparation of bioactive titania films on titanium metal via anodic oxidation. Dent. Mater. 2009, 25, 80-86.

14. Oh, H.J.; Lee, J.H.; Kim, Y.J.; Suh, S.J.; Lee, J.H.; Chi, C.S. Surface characteristics of porous anodic $\mathrm{TiO}_{2}$ layer for biomedical applications. Mater. Chem. Phys. 2008, 109, 10-14.

15. Hu, Y.; Tsai, H.L.; Huang, C.L. Phase transformation of precipitated $\mathrm{TiO}_{2}$ nanoparticles. Mater. Sci. Eng. A 2003, 344, 209-214.

16. Liang, B.; Fujibayashi, S.; Leo, M.; Tamura, J.; Kim, H.M.; Uchida, M.; Kokubo, T.; Nakamura, T. Histological and mechanical investigation of the bone-bonding ability of anodically oxidized titanium in rabbits. Biomaterials 2003, 24, 4959-4966.

17. Ishizawa, H.; Ogino, M. Hydrothermal precipitation of hydroxyapatite on anodic titanium oxide films containing Ca and P. J. Mater. Sci. 1999, 34, 5893-5898.

18. Najafi, H.; Nemati, Z.A.; Sadeguian, Z. Inclusion of carbon nanotubes in a hydroxyapatite sol-gel matrix. Ceram. Int. 2009, 35, 2987-2991.

19. Suchanek, W.; Yoshimura, M. Processing and properties of hydroxyapatite based biomaterials for use as hard tissue replacement implants. J. Mater. Res. 1998, 13, 94-117.

20. Zhang, B.K.; Kwok, C.T. Hydroxyapatite-anatase-carbon nanotube nanocomposite coatings fabricated by electrophoretic codeposition for biomedical applications. J. Mater. Sci. Mater. Med. 2011, 22, 2249-2259.

21. Lin, C.J.; Han, H.J.; Zhang, F.; Li, A.M. Electrophoretic deposition of HA/MWNTs composite coating for biomaterial applications. J. Mater. Sci. Mater. Med. 2008, 19, 2569-2574.

22. Deligianni, D.D.; Katsala, N.; Ladas, S.; Sotiropoulou, D.; Amedee, J.; Missirlis, Y.F. Effect of surface roughness of the titanium alloy Ti-6Al- $4 \mathrm{~V}$ on human bone marrow cell response and on protein adsorption. Biomaterials 2001, 22, 1241-1251.

23. Hautaniemi, J.A.; Juhanoja, J.T.; Herø, H. orcelain bonding on Ti: Its dependence on surface roughness, firing time and vacuum level. Surf. Interface Anal. 1993, 20, 421-426.

24. Zhang, B.; Kwok, C.T.; Cheng, F.T.; Man, H.C. Fabrication of Nanostructured HA/CNT coatings on Ti6A14V by electrophoretic deposition for biomedical applications. J. Nanosci. Nanotechnol. 2011, in press.

25. Kumar, R.R.; Wang, M. Modulus and hardness evaluations of sintered bioceramic powders and functionally graded bioactive composites by nano-indentation technique. Mater. Sci. Eng. 2002, A338, 230-236.

26. Zanello, L.P.; Zhao, B.; Hu, H.; Haddon, R.C. Bone cell proliferation on carbon nanotubes. Nano Lett. 2006, 6, 562-567.

27. George, J.H.; Shaffer, M.S.; Stevens, M.M. Investigating the cellular response to nanofibrous materials by use of a multi-walled carbon nanotube model. J. Exp. Nanosci. 2006, 1, 1-12.

(C) 2012 by the authors; licensee MDPI, Basel, Switzerland. This article is an open access article distributed under the terms and conditions of the Creative Commons Attribution license (http://creativecommons.org/licenses/by/3.0/). 